\section{OBJECTIVES}

Presenting a review of the teratogenicity of mood stabilizers in bipolar disease.

\section{BACKGROUND AND AIMS}

Bipolar disorder is a lifelong mental illness and the symptoms can be exacerbated during pregnancy, therefore the use of mood stabilizers on women is a challenge in pregnancy. The aim of this review is to present the teratogenicity of the mood stabilizers in bipolar disease.

\section{MATERIALS AND METHODS}

Research on Pubmed database using the following keywords: "mood stabilizer", "bipolar disorder" "teratogenicity" and "pregnancy".

We focused on data from systematic reviews and meta-analysis published between 2015 and 2019 in English, Spanish and Portuguese. The articles were selected by the author according to their relevance.

\title{
4. RESULTS
}

- As $50 \%$ of pregnancies are unplanned, the potential risks associated with treatment should be considered when a woman of reproductive age first presents for evaluation.

- Continued psychiatric stability through the perinatal period is imperative; the risks of an untreated psychiatric disorder are just as important, if not more so important, than the risks of psychotropic medication exposure.

- Exposure to one psychotropic medication is safer than exposure to multiple medications.

- Utilize lowest effective dose of medication. However, most risks are not dose dependent, therefore utilize effective therapeutic doses, in order to avoid exposure of the fetus to both psychotropic medications and psychiatric symptoms.

\begin{tabular}{|c|c|c|}
\hline MEDICATION & POTENTIAL COMPLICATIONS & PREGNANCY RECOMMENDATIONS \\
\hline LITHIUM & $\begin{array}{l}\text { Ebstein anomaly }(1 / 1000) \text {. } \\
\text { Lethargy, hypoglycemia, increased birth weight, muscle hypotonicity, } \\
\text { neuromuscular and central nervous system complications. Hypotonia, } \\
\text { respiratory distress and renal dysfunction. } \\
\text { No cognitive or behavioral effects. }\end{array}$ & $\begin{array}{l}\text { Lithium levels should be followed. } \\
\text { The dose should be held or reduced } v \\
\text { the initiation of labor. } \\
\text { Fetal echocardiogram in the } 1 \text { o trimeste } \\
\text { recommended. }\end{array}$ \\
\hline VALPROATE & $\begin{array}{l}\text { Neural tube defects is quite high. Several craniofacial defects (midface } \\
\text { hypoplasia, short nose with anteverted nostrils, and long upper lip). } \\
\text { Linked to autism spectrum disorder. }\end{array}$ & $\begin{array}{l}\text { Should not be used. } \\
\text { High-dose folate supplementation }(4 \mathrm{mg}\end{array}$ \\
\hline CARBAMAZEPINE & $\begin{array}{l}\text { Neural tube defects are increased. Craniofacial defects. } \\
\text { Increased the risk of neonatal hemorrhage }\end{array}$ & $\begin{array}{l}\text { Should not be used. } \\
\text { High-dose folate supplementation }(4 \mathrm{mg}\end{array}$ \\
\hline LAMOTRIGINE & $\begin{array}{l}\text { Lower malformation rates. } \\
\text { No neurodevelopment disorders. }\end{array}$ & $\begin{array}{l}\text { Serum levels should be monitored } \\
\text { maintained during pregnancy as le } \\
\text { usually decrease as pregnancy progresse }\end{array}$ \\
\hline TOPIRAMATE & $\begin{array}{l}\text { Oral clefts, several cardiac defects, hypospadias and coarctation of the } \\
\text { aorta (there are several limitations to these studies). }\end{array}$ & Risk unknown. Should not be used. \\
\hline \multicolumn{3}{|c|}{ 5. CONCLUSIONS } \\
\hline \multicolumn{3}{|c|}{$\begin{array}{l}\text { Women of childbearing should be informed of drugs teratogenic potential and of risks involved in drug switch } \\
\text { discontinuation. Therefore, it is very important to encourage preconception planning. } \\
>\text { With close monitoring, lithium is a first-line mood stabilizer in bipolar disorder management in pregnancy. } \\
>\text { Avoid valproate and carbamazepine, because of the several congenital malformations. } \\
>\text { Lamotrigine can be used with minimal risk of fetal major malformations. } \\
>\text { The risk of topiramate is still unknown. }\end{array}$} \\
\hline
\end{tabular}

REFERENCES: 1)Wichman C.Managing Your Own Mood Lability:Use of Mood Stabilizers and Antipsychotics in Pregnancy.Current Psychiatry Reports.2015; 2))Haskey C. et al.Mood stabilizers in pregnancy and child developmental outcomes: A systematic review.Australian \& New Zealand Journal of Psychiatry.2017; 3) Deligiannidis K. et al.Pharmacotherapy for Mood Disorders in Pregnancy.J of Clin Psychopharm.2014; 4)Payne J.Psychopharmacology in Pregnancy and Breastfeeding. Psychiatric Clinics of North America.2017;5)Ornoy A. et al. Antidepressants, Antipsychotics, and Mood Stabilizers in Pregnancy:What Do We Know and How Should We Treat Pregnant Women with Depression. Birth Defects Research.2017. 